Ethiopian Journal of Environmental Studies \& Management 7 Suppl.: 859 - 869, 2014.

ISSN:1998-0507

doi: http://dx.doi.org/10.4314/ejesm.v7i2.6S

Submitted: October 07, 2014

Accepted: November 28, 2014

\title{
HYDRO-GEOTECHNICAL ASSESSMENT OF AN OPEN WASTE DISPOSAL SITE IN ILORIN, NIGERIA
}

IGE, 0.0.

Department of Geology and Mineral Sciences University of Ilorin, P.M.B 1515 Ilorin, Nigeria

Email: vickyige2002@yahoo.com

\begin{abstract}
This study evaluates effects of leachate from open landfill in the Ita-Amo area of Ilorin, southwestern Nigeria. It also assesses geotechnical properties of in-situ soils samples for possible conversion to sanitary landfill. Results of water analyses showed Electrical Conductivity ranges from $107 \mu \mathrm{s} / \mathrm{cm}$ to $241 \mu \mathrm{s} / \mathrm{cm}$; Sulphate ranges from $98.0 \mathrm{mg} / \mathrm{l}$ to $1400.0 \mathrm{mg} / \mathrm{l}$; $\mathrm{Cl}$ range from $56.4 \mathrm{mg} / \mathrm{l}$ to $880.0 \mathrm{mg} / \mathrm{l}$ during the wet season. In the dry season, Sulphate ranges from $91.7 \mathrm{mg} / \mathrm{l}$ to $1730.0 \mathrm{mg} / \mathrm{l}$; and $\mathrm{Cl}$ ranges from $43.7 \mathrm{mg} / \mathrm{l}$ to $1347.0 \mathrm{mg} / \mathrm{l}$. Concentrations of lead ranges from $41.2 \mu \mathrm{g} / \mathrm{l}$ to $53.4 \mu \mathrm{g} / \mathrm{l}$ and $40.8 \mu \mathrm{g} / \mathrm{l}$ to $61.7 \mu \mathrm{g} / \mathrm{l} ; \mathrm{Zn}^{2+}$ ranges from $57.0 \mu \mathrm{g} / \mathrm{l}$ to $60.0 \mu \mathrm{g} / \mathrm{l}$ and $15.0 \mu \mathrm{g} / \mathrm{l}$ to $67.1 \mu \mathrm{g} / \mathrm{l}$ at wet and dry season respectively. Generally, the concentrations of these parameters are higher than WHO recommendations and decrease away from the centre of the waste dumpsite which is suggesting anthropogenic influence on the water chemistry. Results of Atterberg limits showed that soil samples are inorganic clay of low plasticity with average clay activity value of 0.39 which is suggesting non-reactive kaolinitic clay. Dry density of the soils are $1.80 \mathrm{t} / \mathrm{m}^{3}$ and $2.1 \mathrm{t} / \mathrm{m}^{3}$ when compacted at standard and modified Proctor energies respectively while the coefficient of permeability of the soils are in the order of $1 \times 10^{-9} \mathrm{~m} / \mathrm{s}$ and $1 \times 10^{-11} \mathrm{~m} / \mathrm{s}$ respectively. These results are found favorably compared to recommendations of several researchers. Thus, the soils satisfied the requirements for use as mineral sealants in sanitary landfills. The Modified Proctor is recommended because it offered lower values of coefficient of permeability.
\end{abstract}

Key Words: Hydro-Geotechnical, Assessment, Waste, Ilorin

\section{Introduction}

Suitable land for the disposal of waste is scare in developed cities as a result of population, urbanization and industrialization. It is therefore very common to find waste dumps within built-up areas and cities in bags along roads and streets. Attempts by Nigeria government, groups and individual to check these problems include composting, open burning and river dump of refuse. These attempts had severally failed because of their inadequacies (Ige, 2003, Asiwaju-Bello and Akande, 2004).

The city of Ilorin which falls into Southwestern (Figure 1) and Northcentral on geological and political classifications respectively is the capital town of Kwara State, Nigeria. It has a total land coverage of over $400 \mathrm{~km}^{2}$ (Africa Atlases, 2007) and a population estimate of 2,185,494 people (Onokerhoraye, 2007) which are responsible 
for the generation of waste often deposited in open spaces, river banks, road side etc, thereby degrading the quality of the environment. In an attempt to alleviate environmental pollution within the city, three (3) final waste disposal sites (unengineered) were prepared and located strategically at the outskirt of the city (Figure 2). However, the selection, design, construction and operational activities of these sites did not consider the geology and impacts on the adjacent environment.

This study therefore aims at assessing effects of leachate that is generated on the shallow groundwater of the study area to ascertain the extent of influence on the qualities of such water resources. This is because of environmental degradation effects that commonly associate with other methods of waste disposal without effective containment system (Onipede and Bolaji 2004; and Kurian et al., 2005). The geotechnical properties of clayey materials and other environmental issues were also investigated for the possible upgrading of the site to a modern solid waste containment facility such as sanitary landfill. This is because clayey materials are products of chemical weathering of basement rocks whose geotechnical properties have the potential to be useful as barrier in sanitary landfill (Ige, 2007; Ige et al., 2011 and Oyediran and Adeyemi, 2011).

\section{Study Area}

The study area (Ita-Amo waste disposal site, Ilorin) is located within latitude $8^{\circ} 25^{\prime} \mathrm{N}$ and $8^{\circ} 30^{\prime} \mathrm{N}$ and longitude $4^{\circ} 20^{\prime} \mathrm{E}$ and $4^{\circ}$ $30^{\prime} \mathrm{E}$. The approximate area extent of the dumpsite is $3.63 \times 10^{6} \mathrm{~m}^{2}$ with average dump thickness of about $7.7 \mathrm{~m}$. The site inhabits and still occupying several farm land area. Geologically, the area lies in the Precambrian Basement complex of Nigeria and underlain by rock of metamorphic and igneous type (Obaje, 2009). However, migmatite predominantly underlies the waste dumpsite and characterized by weathered regolith which vary in thickness from place to place (Obaje, 2009). The hydrologic setting of the area studied is typical of what is obtained in other Basement complex area where the availability of water is a function of the presence of thick-little clay overburden material and presence of water filled joints, fracture or faults within the fresh Basement rocks. The humid tropical climate of Ilorin has particularly encourage relatively deep weathering of the near surface rocks to produce porous and permeable material that allows groundwater accumulation as shallow aquifer which is recharged principally through infiltration of rainwater. At the investigated dumpsite, the waste leachate may also infiltrate to pollute the shallow groundwater.

\section{Materials and Methods}

Ten (10) water samples were used in this study (5 samples representing each season). Four (4) shallow water wells were dug around the solid waste deposition centre (1within the dump, 3 outside the dump and a river water sample). The well within the dumpsite is labeled 1while wells at distances "devoid of hydraulic interconnectivity" away from dumpsite and the river water sample are labeled $2,3,4$ and $5(50 \mathrm{~m}, 70 \mathrm{~m}, 120 \mathrm{~m}$ and $327 \mathrm{~m}$ away from dumpsite) respectively. Each of the shallow wells was dug below the groundwater table to provide column for water accumulation (Table 2). The water sampling was done in the wet and dry season to monitor pollution (if any) with respect to season. Each of the water samples was collected into 2-litre container for the determination of anion concentration while 1litre was used for cation concentration determination. The cation containers were acidified with 1-2 drops of $\mathrm{HCl}$ acid to prevent adhering to the surface of the 
container. The sensitive physical parameter such as total dissolve solid (TDS), Electrical conductivity $(\mathrm{Ec})$ and $\mathrm{P}^{\mathrm{H}}$ were determined in the field using portable composite HANNAH - HI9812 pH/TDS/EC meter. Color and turbidity were also measured on the field. The analyses of the chemical constituents of the water sample were carried out at the water laboratory, UNICEF office in Ilorin, Nigeria. Major cations $\left(\mathrm{Mg}^{2+}, \mathrm{Na}^{+}, \mathrm{Ca}^{2+}, \mathrm{K}^{+}\right)$ and anions $\left(\mathrm{HCO}_{3}^{-}, \mathrm{SO}_{4}{ }^{2-}, \mathrm{Cl}^{-}\right)$were analyzed using the flame photometry and atomic absorption photometry method while calorimetric, gravimetric and titrimetric methods were used for the determination of the anions.

Also four soil samples were collected from the shallow wells at different depths within the lateritic zone. The variation in depth of soil sample was necessary to know the geotechnical properties of the whole laterite zone which may be useful as a mineral seals in the construction of modern waste containment facility (sanitary landfill). All the soil samples were analyzed with respect to their grain size distribution, Atterberg limits, moisture content- density relationship and the coefficient of permeability $(\mathrm{K})$ characteristics at the soil laboratory of the Yaba College of technology, Lagos, Nigeria according to the BS 1377: 1990 standard. The results obtained were later compared with the recommendations of several previous researchers and waste regulatory agencies.

\section{Results and Discussions \\ Physical Properties of Water Samples}

Summary of the physical properties (and some site characteristics) of water sample is presented in Table 1. The $\mathrm{P}^{\mathrm{H}}$ value ranges between $6.8-7.9$ at both seasons. This range falls within the acceptable boundary of (WHO, 2011) for water usage in drinking. The colour value range between 15 Hazen -
61 Hazen units in the wet season and 50Hazen - 92Hazen in dry season with highest value observed at well 1. Turbidity is higher in dry season than in wet season, probably due to dilution activities in the wet season, and decreases away from the dumpsite area (Table 1).

\section{Chemical Properties of Water Samples}

The relative abundance of the elements is shown in Table 2. The calcium ion concentration range from $7.4 \mathrm{mg} / \mathrm{l}-64 \mathrm{mg} / \mathrm{l}$ and $41 \mathrm{mg} / \mathrm{l}-121.4 \mathrm{mg} / \mathrm{l}$ during wet and dry season respectively. While the magnesium ion concentration range from $17.0 \mathrm{mg} / 1-61.0$ $\mathrm{mg} / \mathrm{l}$ and $17.0 \mathrm{mg} / \mathrm{l}-100.4 \mathrm{mg} / \mathrm{l}$ during wet and dry season respectively. Concentration of sodium ion range from $12.0 \mathrm{mg} / 1-57.5 \mathrm{mg} / 1$ in the wet season, and $23.0 \mathrm{mg} / \mathrm{l}$ to $109.4 \mathrm{mg} / \mathrm{l}$ in the dry season while potassium ion concentration range from $0.78 \mathrm{mg} / \mathrm{l}-2.70 \mathrm{mg} / \mathrm{l}$ and $1.30 \mathrm{mg} / \mathrm{l}-14.0 \mathrm{mg} / \mathrm{l}$ during wet and dry season respectively. Calcium concentration falls below the maximum permissible level (MPL) of their concentration in water to be useful for drinking purpose (WHO, 2011). This may be due to little or no interaction of water with the underlying basement rock (the principal source of calcium and magnesium ion) since all water samples were collected within vadose zone.

However, concentrations above allowable level were noticed at wells 1, 2 and 3 in dry season and decreases with distance away from the centre of the dumpsite (Figures 312).

For the anions, bicarbonate concentrations range from $93.5 \mathrm{mg} / 1$ $250 \mathrm{mg} / \mathrm{l}$ in the wet season and from $91.8 \mathrm{mg} / \mathrm{l}$ - 234.0mg/l in dry season. The sulphate range from $98.0-1400.0 \mathrm{mg} / \mathrm{l}$ and $91.7 \mathrm{mg} / \mathrm{l}$ $1730.4 \mathrm{mg} / \mathrm{l}$ in the wet and dry season respectively. The chloride ion concentration range from $56.4 \mathrm{mg} / \mathrm{l}-880.0 \mathrm{mg} / \mathrm{l}$ ion in the wet and from $43.7 \mathrm{mg} / \mathrm{l}-1347.0 \mathrm{mg} / \mathrm{l}$ in the dry season. The nitrate ion concentrations 
(where determined) range from $17.0 \mathrm{mg} / \mathrm{l}$ $31.0 \mathrm{mg} / \mathrm{l}$ and $20.1 \mathrm{mg} / 1-53.4 \mathrm{mg} / \mathrm{l}$ at the two season respectively. All the parameters (anions) were observed to be above MPL at the wells (1-4) during the two seasons and decrease away in concentration from dumpsite centre (Table 2). This may be connected to liquefaction and leaching of decomposed dominantly domestic, liquidindustrial and commercial waste within the dumpsite as a result of the action of heat, pressure and presence of water. Generally, low concentrations of these parameters were observed which may be due to pollutant filtering capability of the underlying soil, season and age of dumpsite.

\section{Geotechnical Properties of Soils}

Several limits have been proposed by various researchers with respect to geotechnical properties of soils to be useful as barriers in landfills. Such limits have been compared with the results of the investigated parameters and presented as follows;

\section{Grain Size Distribution}

In the soils investigated the largest grain has diameter $\leq 6.3 \mathrm{~mm}$. This is very small compare to $63 \mathrm{~mm}$ suggested by ÖNORM S2074 (1990) and less than 50mm suggested by Daniel 1993 . The percentage of clay contained in the soil range between $41 \%$ $51 \%$ Table 3. These values are much higher than $15 \%$ proposed by ÖNORM S 2074 (1990) and less than 30\% suggested by Daniel (1993), Bagchi (1994), Benson et al. (1994), Rowe (2005) and Mohammedzein (2005). Oeltzcshner (1992) preferred soils with clay fraction of greater than $20 \%$. The percentage of gravel recommended by Daniel 1993, Bagchi (1994) and Rowe (1995) is less or equal $30 \%$ of the soil mass. The highest proportion of gravel from the investigated soil sample is $2 \%$ with an average value of $0.75 \%$ over the whole area. The specific gravity values also range between $2.61 \%$ and
$2.69 \%$ which is better than 2.2 recommended by ÖNORM S2074 (1990).

\section{Atterberg Consistency Limits}

The results of the liquid limits tests $\left(\mathrm{L}_{1}\right)$ for the soil range between $35.34 \%$ and $40.56 \%$ while the index of plasticity (Ip) range between $17.15 \%$ and $20.55 \%$ (Table 4 ). These are higher than recommendations of several previous workers. From the results, the Casangrande plasticity chart was plotted for all the soils. All the soil samples fall within the inorganic clay of intermediate plasticity (Fig. 13). This is a good result when compared to the recommendations of Bagchi (1994), and Ash and Jagger (2008). Clay activities $\left(A_{C}\right)$ of the soils were also evaluated to determine the reactivity of the soil. The values range between 0.35 and 0.40 . It therefore suggested that the soil contain essentially kaolinitic clay mineral type which are non-reactive and non-expansive (Bagchi, 1994 and Withlow, 1998). They are less attack by chemical and withstand volumetric shrinkage (Kabir and Taha, 2006).

\section{Moisture Content - Density Relationship}

The results of compaction tests carried out at different energies of compaction to obtain the soils optimum moisture content (OMC) and the corresponding maximum dry density (MDD) is presented in the Table 5. Benson and Trast (1995) reported that the coefficient of permeability is sensitive to compactive effort and molding water content. The soil MDD values for standard Proctor energy of compaction range between $1.77 \mathrm{t} / \mathrm{m}^{3}$ and $1.84 \mathrm{t} / \mathrm{m}^{3}$ while MDD at modified Proctor energy range between $1.9 \mathrm{t} / \mathrm{m}^{3}$ and $2.2 \mathrm{t} / \mathrm{m}^{3}$. These values are higher than $1.7 \mathrm{t} / \mathrm{m}^{3}$ stipulated in ÖNORM S 2074 (1990). They are also better than $1.45 \mathrm{t} / \mathrm{m}^{3}$ (under standard Proctor energy) and $1.64 \mathrm{t} / \mathrm{m}^{3}$ (under modified Proctor energy) of MDD recommended by kabir and Taha (2006) for soils produced from Basement complex rocks to be useful as barrier in landfills. 


\section{Coefficient of Permeability $(\boldsymbol{k})$}

The coefficient of permeability is the key parameter affecting most soils to be useful as barrier in landfill (Benson and Daniel, 1990). Thus great attention is focused at ensuring a low permeability is achieved. Several investigators and waste management agencies have recommended $1 \times 10^{-9} \mathrm{~m} / \mathrm{s}$ as the minimum allowable value for soil to be useful for this purpose. From Table 5, values lower than recommendation of several authors (e.g Mark 2002; Joyce 2003; and Ash and Jagger, 2008) were obtained from all the soil investigated with both standard and modified Proctor energies. It was also observed that the coefficient of permeability decreases with increased compactive energy (Table 5). This is because there is a decrease in the frequency of pores resulting from the structural rearrangement of soil particle in the soil mass (Acar and Oliveri, 1990). For the purpose of sanitary landfill, the least achievable coefficient of permeability on the field is preferred. Therefore the higher energy (modified Proctor) of compaction is recommended.

\section{Conclusion}

The following conclusions were made on the hydrogeological and geotechnical evaluation of the Ita-amo waste dumpsite in, Ilorin, Nigeria.

The physical properties of the water samples are quite lower than the allowable recommended by the WHO for drinking and irrigation purpose. However, there is seasonal influence on the cationic concentration in the dry season with wells 1,2 and 3 having concentration above the WHO permissible level. Also, Liquefaction and leaching activities of the deposited large volume of domestic and liquid -industrial waste at site may have been responsible for the high increase in the ionic concentration at both seasons. Expectedly, ionic concentration decreases with increase distance away from the waste dump center. This confirms the potential danger of the waste dumping activity on the neighboring environment.

The overall engineering characteristics of the soil samples recovered from test pits, irrespective of the depth of recovery, show that the soils are inorganic clay with low to medium plasticity. Generally, these types of soils possess desirable characteristics to minimize hydraulic conductivity of compacted soils. The index properties (liquid limit, plastic limit, percentage fine, percentage gravel, activity etc) of the soil samples satisfy the basic requirements as barrier materials in landfills. They are inactive clayey soils. Thus, the soils will be less affected by waste chemical and also less susceptible to shrinkage. The soils have hydraulic conductivity of less than $1 \times 10^{-9}$ $\mathrm{m} / \mathrm{s}$ when compacted with both modified and standard Proctor compaction efforts.

This result compared favorably with the recommendations of several researchers. Also higher energy of compaction is recommended because it gives lower values of coefficient of permeability for the compacted soils.

\section{Acknowledgements}

The author is grateful to Prof. O. Ogunsanwo, Department of Geology and Mineral Sciences, University of Ilorin for many useful suggestions during the study. He is also thankful to the University of Ilorin community for providing enabling environment to carry out the research.

\section{References}

Acar, Y. and Oliveri, I. (1990). Pore Fluid Effects on the fabric and Hydraulic Conductivity of Laboratory Compacted Clay. United State Transportation Research Record 12(19): 144-159. 
Africa Atlasses (2007). Atlas of Nigeria. $2^{\text {nd }}$ edition. $156 \mathrm{p}$.

Ash, J.S. and Jagger, D.E. (2008). Geotechnical considerations at landfill site. Jagger. Hims Ltd. www.jaggerhims.com, 27p.

Asiwaju-Bello, Y.A, and Akande, O.O. (2004). Urban groundwater pollution: Case study of a Disposal sites in Lagos metropolis. Journal of Water Resources, 12: 22-26.

Bagchi, A. (1994). Design, Construction, and Monitoring of landfills. $2^{\text {nd }}$ Edition, A Wiley-Interscience Publisher. New York, U. S. A. 361p.

Benson, C.H. and Daniel, D.E. (1990). The effect of clods on hydraulic Conductivity of compacted clay. Journal of Geotechnical Engineering. 116(8): 1237-1248.

Benson, C.H., Zhai, H. and Wang, X. (1994). Estimating hydraulic conductivity of compacted clay liners. Journal of Geotechnical Engineering. 120(2): 336-387.

Benson, C.H and Trast, M.J. (1995). Hydraulic conductivity of Thirteen compacted Clays. Clays and clay minerals, 43(6): 669-681.

Daniel, D.E. (1993). Clay Liners. In: Geotechnical Practice for Waste Disposal (Daniel D.E ed). Chapman Hall, London, U.K, 137-163.

Ige, O.O. (2003). Impact of cultural and industrial waste on surface and shallow ground water along Asa River, Ilorin metropolis, Kwara State, Nigeria. University of Ilorin, Geology and Mineral Sciences, M.Sc., Unpublished Thesis. 108p.

Ige, O.O. (2007). Engineering Geological Assessment of some soils from Southwestern Nigeria as mineral seals in Sanitary Landfills. Nigerian Journal of Pure and Applied Sciences. 22: 2063-2069.

Ige, O.O., Ogunsanwo, O. and Inyang, H.I. (2011). Characterization of Terrain and Biotite Gneiss-Derived Lateritic soils of Ilorin, Nigeria, for use in Landfill Barriers. Global Journal of Geological Sciences, 9(1): 1-9.

Joyce, M.P.E. (2003). A study of the merit and effectiveness of alternate liner Systems at Illinois landfills. A research paper submitted in fulfillment of house resolution 715. State of Illinois $92^{\text {nd }}$ General Assembly. 46p.

Kabir, M.H and Taha, TR. (2006). Sedimentary Residual soils as a hydraulic barrier in waste containment systems. $2^{\text {nd }}$ International Conference on Advances in soft soil Engineering. Technology Putrajaya, Malaysia. 894904.

Kurian, J., Nagendran, R. and Palanivelu, P. (2005). Open Dumps to Sustainable Landfill. Centrefor Environmental Studies, Anna University, Channai, India.

www.serd.ait.ac.th/sidaSWM/project

Mark, Y. (2002). Geology and Geotechnical Investigation of the proposed anterbury Regional Landfill Kate Valley, North Canterbury Transwaste Canterbury Ltd. $147 \mathrm{p}$.

Obaje, N.G. (2009). Geology and Mineral resources of Nigeria. Srpiner-Verlag Berlin Heidelberg. 122p.

Onokerhoraye, A.G. (2007), "Population and Demography of Nigeria". Africa Atlass-Nigeria. 2nd Edition. 156p.

Onipede, M.A and Bolaji, B.O. (2004). Management and disposal of industrial wastes in Nigeria. Nigerian Journal of Mechanical Engineering. 2(1): 49-63.

Oyediran, I.A. and Adeyemi G.O. (2011). Geotechnical investigations of a site in Ajibode, Southwestern Nigeria for 
Landfill. Ozean Journal of Applied Sciences, 4(3): 265 -279.

Rowe, R. K. (2005). Long-term performance of contaminant barrier systems. Geotechnique. 55(9): 631-678.
Withlow, R. (1998). Basic Soil Mechanics. $3^{\text {rd }}$ Edition. Longman Group Ltd. 557p. World Health Organization (2011). Guidelines for Drinking-water Quality. Recommendations. Geneva. 518p.

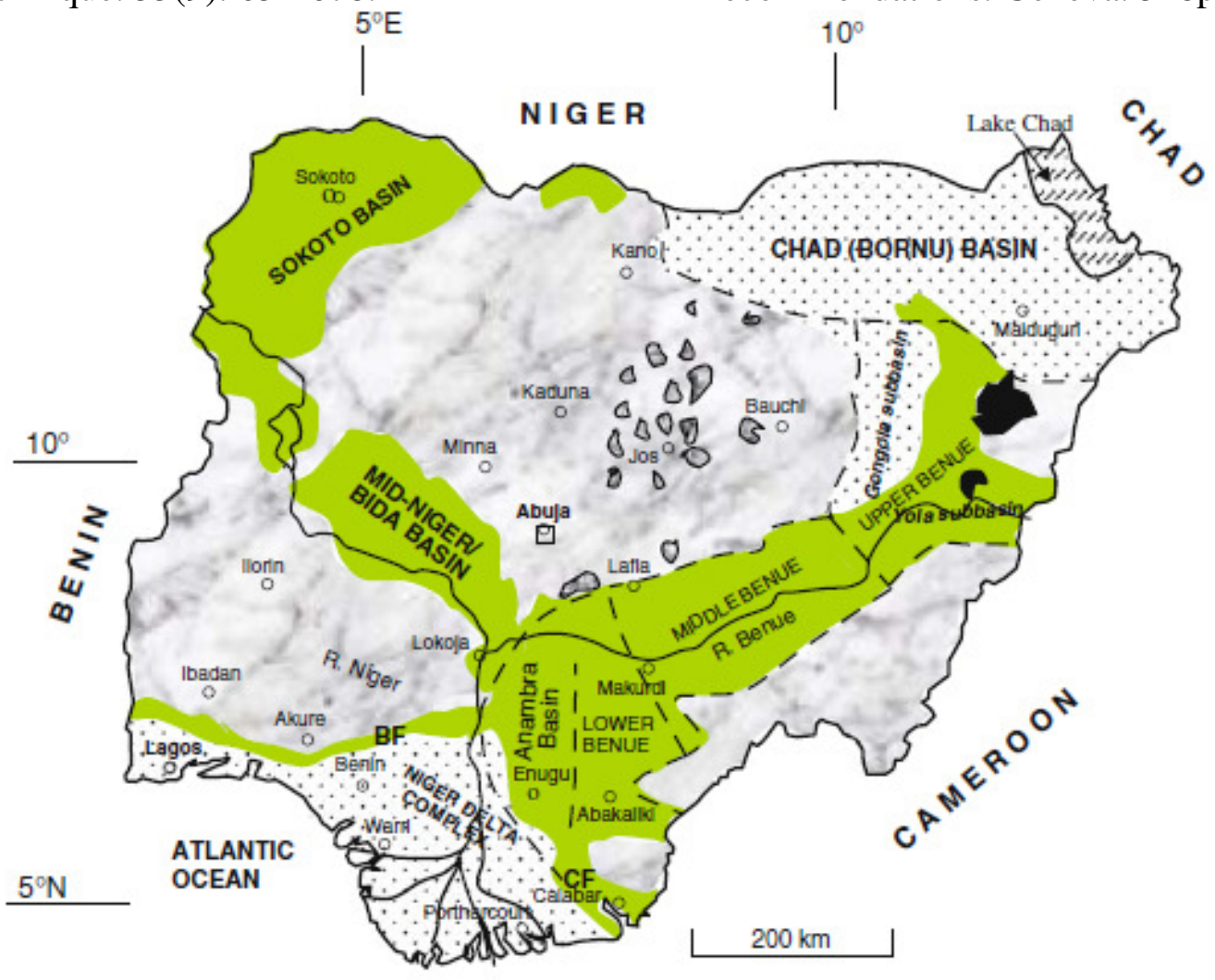

\begin{tabular}{|c|c|c|c|}
\hline & $\begin{array}{l}\text { Tertiary - Recent } \\
\text { sediments } \\
\text { Tertiary volcanics }\end{array}$ & $\Delta D$ & Jurassic Younger Grantes \\
\hline & & & | Precambrian Basement \\
\hline & Cretaceous & $\circ$ & Major (reference) town \\
\hline & Calabar Flank & & \\
\hline
\end{tabular}

Figure 1: Geological map of Nigeria showing Ilorin (Obaje, 2009) 


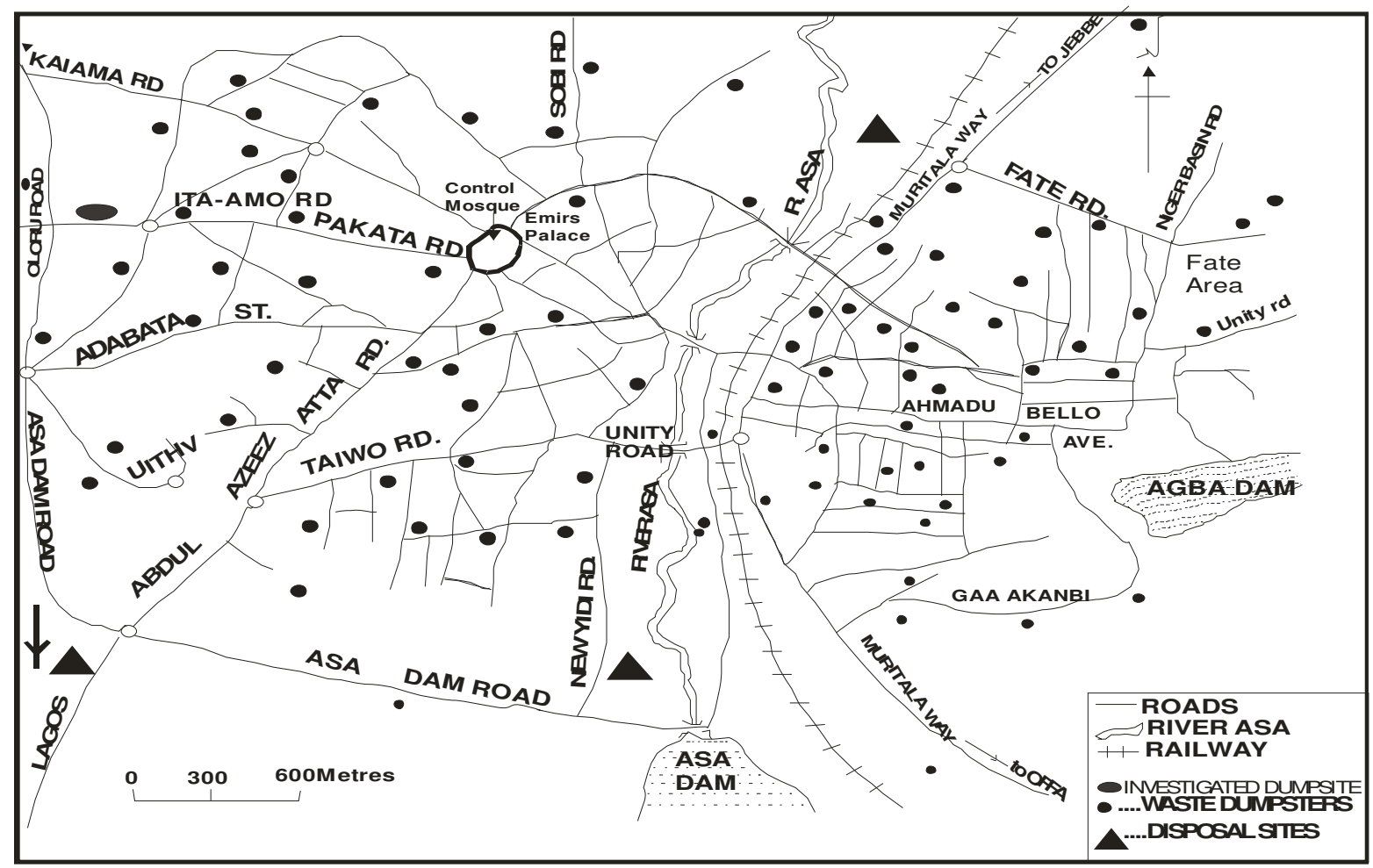

Figụre 2 : The Locations of waste dumpsters and final disposal site in Ilorin.

Table1: Physical Properties of Water Sample and other Site Characteristics.

\begin{tabular}{llllll}
\hline Properties & W1 & W2 & W3 & W4 & SW \\
\hline Static water level (m) & 5.71 & 6.30 & 6.57 & 4.9 & - \\
Depth of Well (m) & 6.47 & 6.47 & 7.15 & 6.71 & - \\
Thickness of clayey & 3.90 & 3.58 & 3.84 & 3.79 & - \\
horizon(m) & & & & & \\
Depth of soil sampling (m) & 1.15 & 2.70 & 4.50 & 3.10 & - \\
\hline
\end{tabular}

W1- 4: Well Number

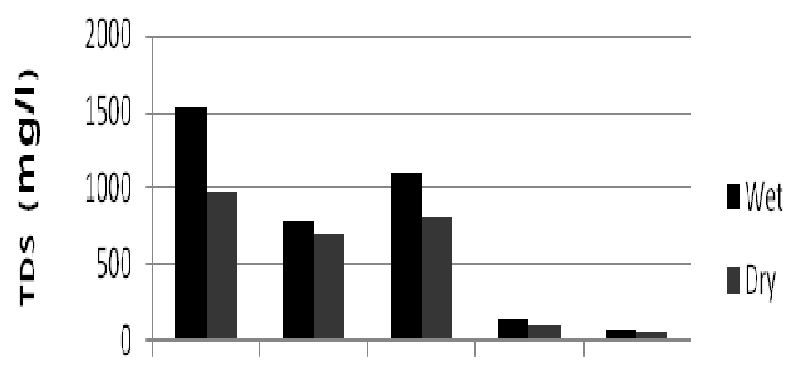

W1 W2 W3 W4 W5

Figure 3: Concentration of Total Dissolved Solid

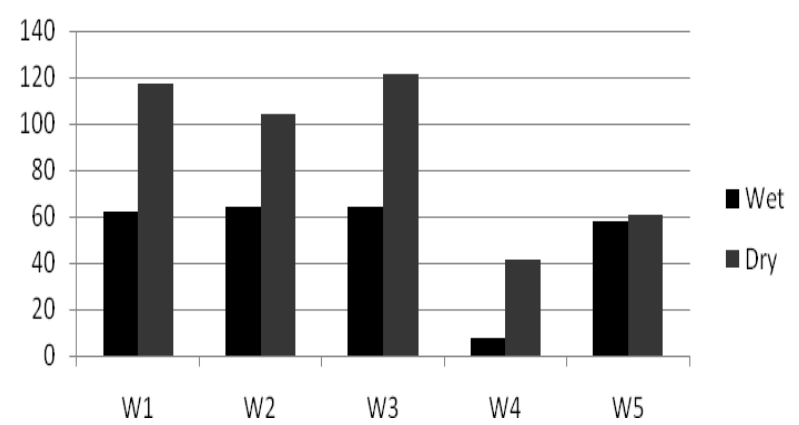

Figure 4: Variation of Calcium concentration 
Ethiopian Journal of Environmental Studies and Management Vol. 7 Suppl. 2014

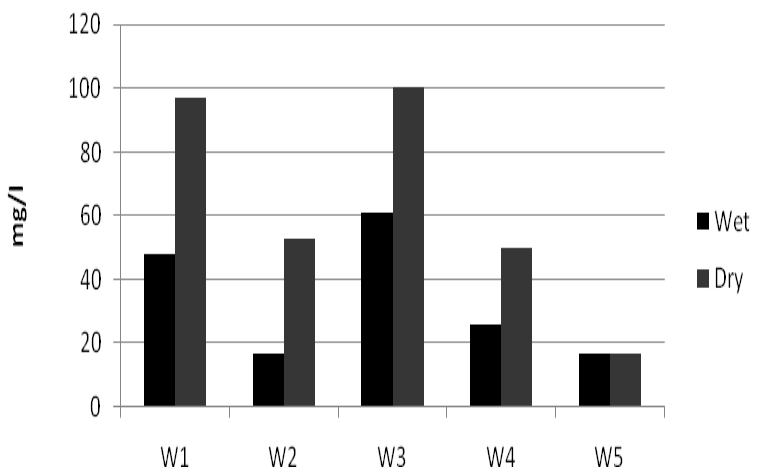

Figure 5: Variation of Magnesium ion concentration

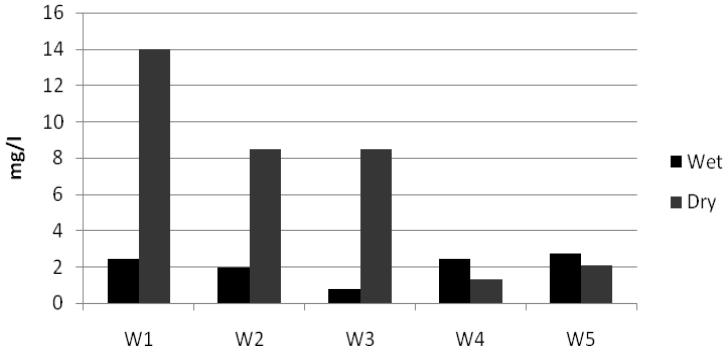

Figure 6: Variation of Potassium ion concentration

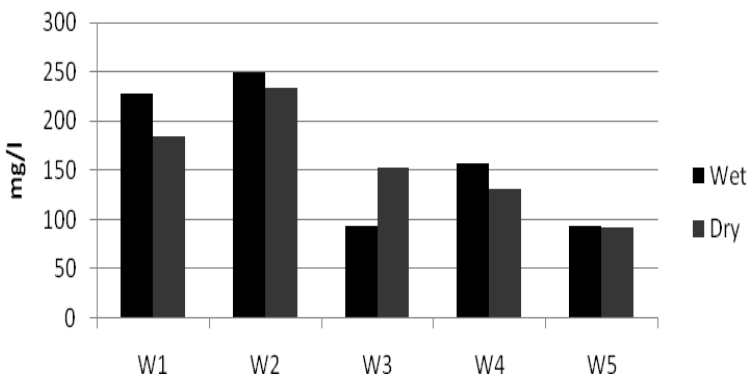

Figure 7: Variation of Bicarbonates ion concentration in the wells

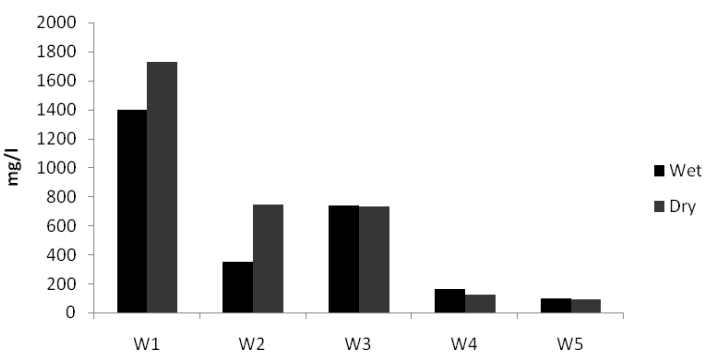

Figure 8: Variation of Sulphate ion concentration in the wells

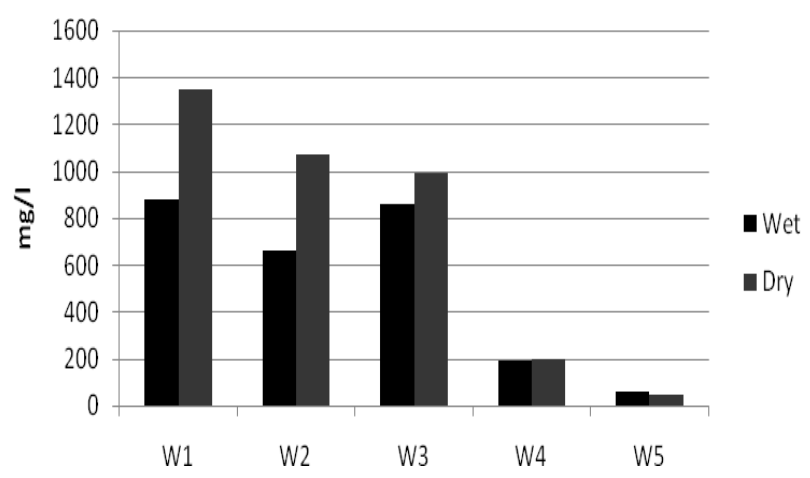

Figure 9: Variation of Chloride ion concentration

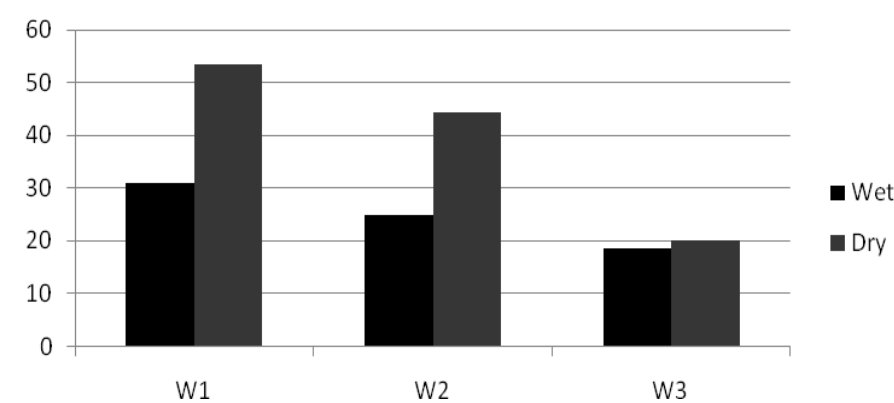

Figure 10: Variation of Nitrate ion concentration

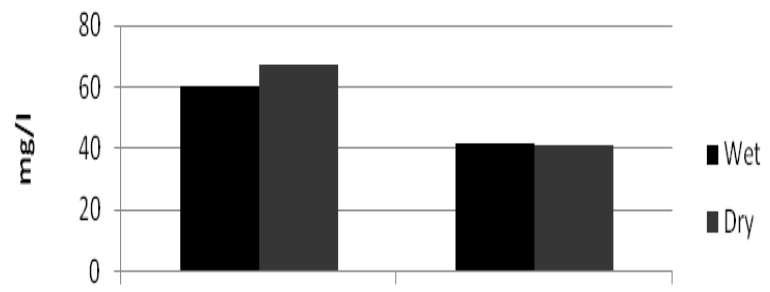

W1

W2

Figure 11: Variation of Zinc ion Concentration

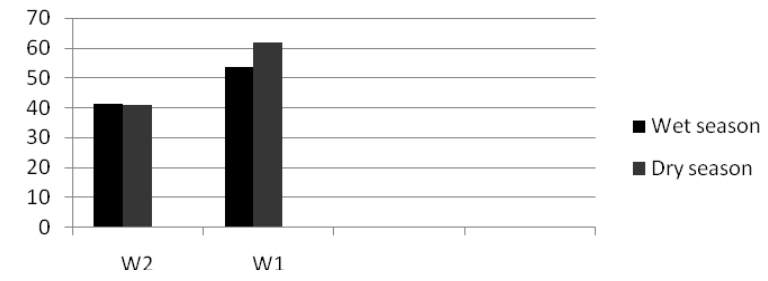

Figure 12: Variation of Lead ion concentration 
Table 2: Chemical Properties of Water Samples

\begin{tabular}{lllllllllllll}
\hline Parameters & Wet & Dry & Wet & Dry & Wet & Dry & Wet & Dry & Wet & Dry & AL & MPL \\
\hline $\mathrm{pH}$ & 7.1 & 6.6 & 7.2 & 6.8 & 7.6 & 7.1 & 7.4 & 7.1 & 7.9 & 7.0 & - & \\
Ec $(\mu \mathrm{s} / \mathrm{cm})$ & 3320 & 2411 & 1585 & 1034 & 2360 & 1917 & 500 & 439 & 160 & 107 & - & 400 \\
TDS $(\mathrm{mg} / \mathrm{l})$ & 1530 & 971 & 785 & 704 & 1110 & 816 & 142 & 101 & 74 & 61 & - & 1000 \\
Calcium $(\mathrm{mg} / \mathrm{l})$ & 62.0 & 117.2 & 64.0 & 104.4 & 64.0 & 121.4 & 7.4 & 41.3 & 58.0 & 61.0 & 75.0 & 200.0 \\
Magnesium $(\mathrm{mg} / \mathrm{l})$ & 48.0 & 97.2 & 17.0 & 53.0 & 61.0 & 100.4 & 26.0 & 50.0 & 17.0 & 17.0 & 50.0 & 150.0 \\
Sodium $(\mathrm{mg} / \mathrm{l})$ & 12.0 & 49.4 & 57.5 & 109.4 & 12.0 & 61.1 & 23.0 & 27.0 & 25.0 & 23.0 & 20.0 & 200.2 \\
Potassium $(\mathrm{mg} / \mathrm{l})$ & 2.4 & 14.0 & 1.95 & 8.5 & 0.78 & 8.5 & 2.4 & 1.3 & 2.7 & 2.1 & 10.0 & 12.0 \\
Bicarbonate(mg/l) & 228.1 & 184.2 & 250.0 & 234.0 & 93.5 & 153.3 & 157.4 & 131.0 & 94.1 & 91.8 & variable & Variable \\
Sulphate $(\mathrm{mg} / \mathrm{l})$ & 1400 & 1730.4 & 350.0 & 742.7 & 740.1 & 733.6 & 160.0 & 120.0 & 98.0 & 91.7 & 250.0 & 400 \\
Chloride $(\mathrm{mg} / \mathrm{l})$ & 880.0 & 1347.0 & 664.1 & 1074.1 & 860.0 & 994.4 & 193.9 & 200.7 & 56.4 & 43.7 & 250.0 & 600 \\
Nitrate $(\mathrm{mg} / \mathrm{l})$ & 31.0 & 53.4 & 24.7 & 44.4 & 18.4 & 20.0 & ND & ND & 17.0 & 20.1 & 25.0 & 50.0 \\
Zinc $(\mu \mathrm{g} / \mathrm{l})$ & 60.0 & 67.1 & 57.2 & 61.0 & ND & 15.4 & ND & ND & - & - & - & 50 \\
Lead $(\mu \mathrm{g} / \mathrm{l})$ & 53.4 & 61.7 & 41.2 & 40.8 & ND & ND & ND & ND & - & - & - & 50 \\
Nickel $(\mu \mathrm{g} / \mathrm{l})$ & 30.3 & 33.1 & ND & 17.4 & ND & ND & ND & ND & - & - & - & 50 \\
Colour $(\mathrm{Hazen})$ & 61.4 & 92.3 & 53.4 & 68.1 & 51.4 & 60.7 & 15.5 & 50.6 & 31.4 & 56.1 & 5 & 50 \\
Turbidity & 21.7 & 28.2 & 17.0 & 33.9 & 9.3 & 20.3 & 7.7 & 7.3 & 12.8 & 7.2 & - & \\
\hline
\end{tabular}

Table 3: Grain size analysis of soil samples

\begin{tabular}{|c|c|c|c|c|c|c|c|c|c|}
\hline $\mathrm{S} / \mathrm{N}$ & $\begin{array}{l}\text { Well } \\
\text { No }\end{array}$ & $\operatorname{Depth}(\mathrm{m})$ & $\begin{array}{l}\text { Natural } \\
\text { Density }\left(\mathrm{t} / \mathrm{m}^{3}\right)\end{array}$ & $\begin{array}{l}\text { Specific } \\
\text { Gravity }\end{array}$ & $\begin{array}{l}\text { Grain } \\
\text { Size } \\
(\%)\end{array}$ & $\begin{array}{l}\text { Sand } \\
(\%)\end{array}$ & $\begin{array}{l}\text { Clay } \\
(\%)\end{array}$ & $\begin{array}{l}\text { Silt } \\
(\%)\end{array}$ & $\begin{array}{l}\text { Fine } \\
(\%)\end{array}$ \\
\hline 1 & W1 & 1.15 & 2.04 & 2.69 & 2 & 28 & 48 & 22 & 70 \\
\hline 2 & W2 & 2.70 & 1.67 & 2.64 & 1 & 34 & 45 & 20 & 65 \\
\hline 3 & W3 & 4.50 & 1.60 & 2.63 & 0 & 28 & 51 & 2 & 72 \\
\hline \multirow[t]{2}{*}{4} & W4 & 3.10 & 1.91 & 6.61 & 0 & 36 & 49 & 15 & 64 \\
\hline & & Average & 1.81 & 2.64 & 0.75 & 32 & 48.3 & 19 & 68 \\
\hline
\end{tabular}

Table 4: Atterberg Consistency limits of the soil samples

\begin{tabular}{lccccc}
\hline & & & \multicolumn{2}{c}{$\begin{array}{l}\text { Plots on Plasticity } \\
\text { chart }\end{array}$} \\
\hline Wymbol & WL $(\%)$ & WP $(\%)$ & IP $(\%)$ & CL & 0.35 \\
W2 & 35.34 & 18.19 & 17.15 & CI & 0.41 \\
W3 & 39.14 & 20.80 & 18.34 & CI & 0.39 \\
W4 & 39.80 & 21.31 & 18.49 & CI & 0.42 \\
Average & 40.56 & 20.01 & 20.55 & CI & 0.39 \\
\hline KEY: WL = Liquid Limit & & 18.63 & WP = Plastic Limit \\
\multicolumn{2}{l}{ IP = Index of Plasticity } & & Ac = Activity of Clay
\end{tabular}




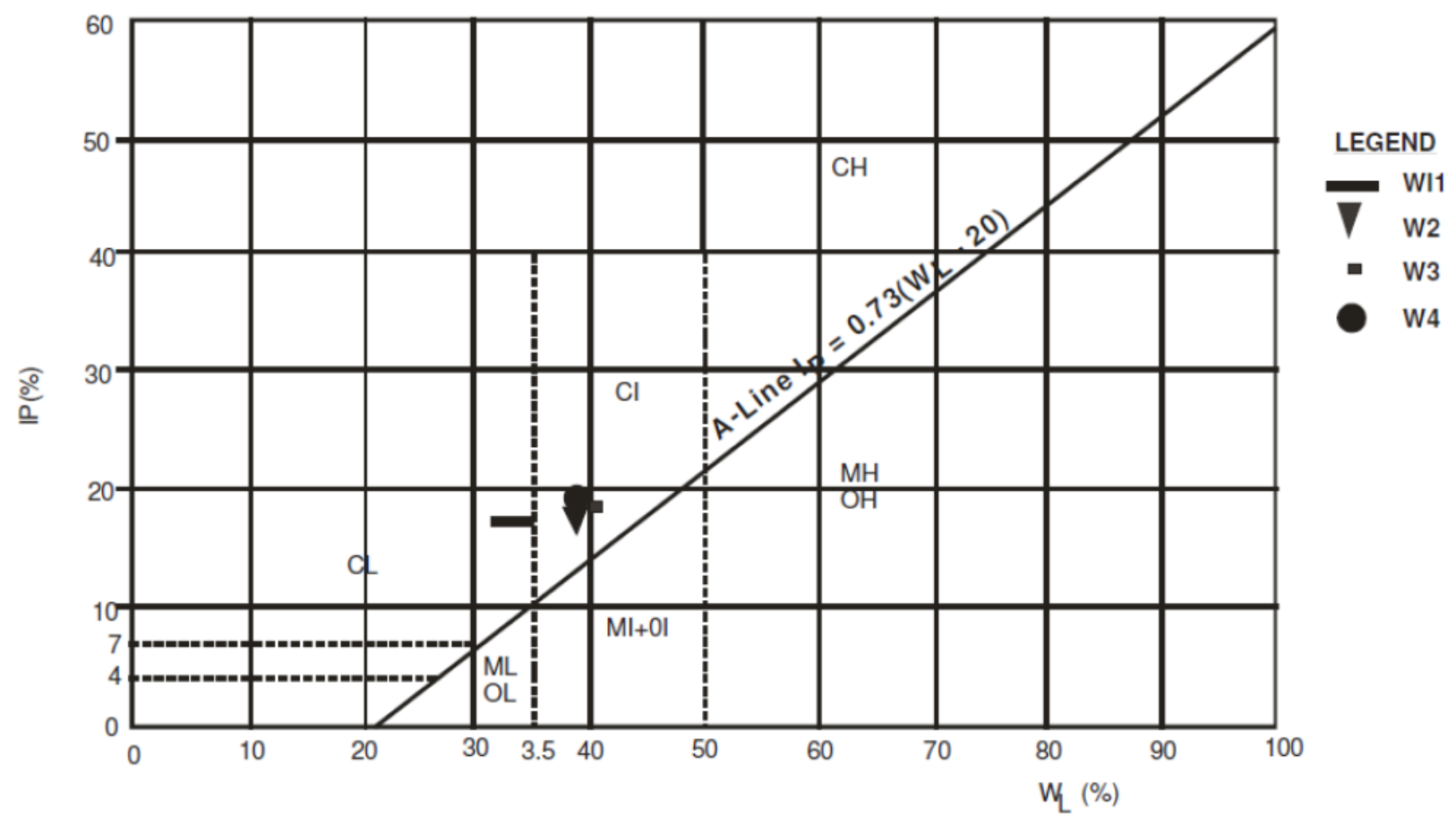

Figure 13: Position of soil samples on the Casagrande's Plasticity chart

Table 5: Maximum Dry Density and Coefficient of Permeability of the soil Samples.

\begin{tabular}{|l|l|l|l|l|l|l|}
\hline $\begin{array}{l}\text { WELL } \\
\text { SYMBOL }\end{array}$ & \multicolumn{2}{l|l|l|l|l|}{$\begin{array}{l}\text { STANDARD } \\
\text { PROCTOR }\end{array}$} & \multicolumn{2}{l|l}{$\begin{array}{l}\text { MODIFIED } \\
\text { PROCTOR }\end{array}$} & \multicolumn{2}{l|}{$\begin{array}{l}\text { COEFFICIENT OF } \\
\text { PREMEABILITY }(K) \mathrm{cm} / \mathrm{s}\end{array}$} \\
\hline & OMC $(\%)$ & $\begin{array}{l}\text { MDD } \\
\left(\mathrm{t} / \mathrm{m}^{3}\right)\end{array}$ & OMC $(\%)$ & $\begin{array}{l}\text { MDD } \\
\left(\mathrm{t} / \mathrm{m}^{3}\right)\end{array}$ & $\begin{array}{l}\text { STANDARD } \\
\text { PROCTOR }\end{array}$ & $\begin{array}{l}\text { MODIFIED } \\
\text { PROCTOR }\end{array}$ \\
\hline W1 & 13.4 & 1.84 & 10.8 & 2.2 & $1.1 \times 10^{-9} \mathrm{~m} / \mathrm{s}$ & $3.4 \times 10^{-11} \mathrm{~m} / \mathrm{s}$ \\
\hline W2 & 14.0 & 1.78 & 10.3 & 1.9 & $4.0 \times 10^{-9} \mathrm{~m} / \mathrm{s}$ & $5.1 \times 10^{-11} \mathrm{~m} / \mathrm{s}$ \\
\hline W3 & 14.2 & 1.77 & 10.0 & 2.1 & $5.3 \times 10^{-8} \mathrm{~m} / \mathrm{s}$ & $3.6 \times 10^{-11} \mathrm{~m} / \mathrm{s}$ \\
\hline W4 & 16.7 & 1.80 & 12.5 & 2.0 & $3.7 \times 10^{-9} \mathrm{~m} / \mathrm{s}$ & $2.3 \times 10^{-11} \mathrm{~m} / \mathrm{s}$ \\
\hline AVERAGE & 14.6 & 1.80 & 10.9 & 2.1 & $3.53 \times 10^{-8} \mathrm{~m} / \mathrm{s}$ & $1.6 \times 10^{-11} \mathrm{~m} / \mathrm{s}$ \\
\hline
\end{tabular}

OMC $=$ Optimum Moisture Content

MDD = Maximum Dry Density 